\title{
Ethnic Group Representativeness and the Effect on Political Conflict
}

Tholen, Anne Lina ${ }^{1}$

\begin{abstract}
This paper looks at the relationship between the underrepresentation of ethnic minority groups in governments and the effect on violence and conflict that is initiated by these groups. Ethnic minority groups that are underrepresented in political decision-making are likely to express their opinions outside of the political routine, by means of conflict. Three potential determinants of representation are analyzed. An increase in the effective number of parliamentary parties is expected to lead to more ethnic groups being represented and thus to a decrease in conflict. A more proportional electoral system or electoral type should lead to more parties in parliament and to a more proportionate depiction of society, thus including ethnic minority groups more adequately and decreasing conflict. An increase in the share of seats of parties classified as ethnic relative to the share of the population held by ethnic groups, the share ratio, yields more proportional representation and should therefore also result in less conflict. Empirical analysis of a sample of 52 countries consistently supports the predictions regarding the share ratio, while the rest of the theory cannot be supported reliably. The results should be evaluated with caution due to an apparent mismatch between ethnic groups and ethnic parties.
\end{abstract}

"The principal difficulty lies, and the greatest care should be employed in constituting this representative assembly. It should be in miniature an exact portrait of the people at large. It should think, feel, reason and act like them. That it may be the interest of the assembly to do

strict justice at all times, it should be an equal representation, or, in other words, equal interests among the people should have equal interests in it. Great care should be taken to effect this, and to prevent unfair, partial and corrupt elections."

- John Adams, Thoughts on Government, 1776

\section{Introduction}

The last months and years have been marked by ongoing political and social turbulences in various parts of the world. Civil protests and differences of opinion between Ukrainian- and Russian-speaking people in the Ukraine brought about a regime change in early 2014, with the political and social consequences being not yet fully clear. According to a 2001 census carried out by the Ukrainian State Statistic Committee, 17.3 percent of the population identify themselves as being of Russian ethnicity. This ethnic minority plays a significant role in the

\footnotetext{
${ }^{1}$ Anne Lina Tholen received a bachelor degree in International Economic Studies at Maastricht University in 2014. At the moment she takes a gap year during which she completes three internships; at DZ Bank, the European Parliament and the European Stability Mechanism Contact: anne.lina@online.de
} 


\section{Ethnic Group Representativeness}

ongoing political conflict. Between 2010 and 2013 a wave of revolutions in Arab countries coined the term Arab Spring, with government power changing in countries such as Egypt, Yemen, Libya and Tunisia. Several of these national revolutions were sparked due to governments or dictators not adequately representing the opinions of the people. In Libya the ethnic minority of the Berbers, who are indigenous to North Africa and make up about five percent of the Libyan population, have actively taken part in the revolutions in order to be more widely recognized. In Morocco they were successful in making their language official in 2011 (The Economist, 2011). In Syria and Iraq the ethnic group of the Kurdish people joined in on the protests and received concessions in the form of granted citizenship in Syria (Therolf \& Sandels, 2011). The level of violence involved in those events differed greatly from solely vocal protests in Oman to civil war in countries such as Tunisia. Violent deaths and government overthrows are among the most pronounced short-term effects of the above mentioned incidences. The long-term effect is likely to be an economic disadvantage for the countries involved.

Researchers such as Bates (2001) and North, Wallis and Weingast (2009) argue that political violence and turmoil decrease countries' economic growth and prosperity. Bates states that political development "involves the taming of violence" (Bates, 2001, p.13). He claims that when political institutions that tame violence fail, violence leads to a slowdown of economic growth. This is because an environment marked by conflict gives very few incentives for investment and entrepreneurial spirit. North et al. (2009) state that open access orders with broad access to politics for all parts of the population, are effective in limiting violence. They therefore conclude that richer states can be commonly shown to be open access orders. Busse and Hefeker (2007) show a more financial view on the topic. They find that government stability is significantly positively, while conflict and ethnic tensions are significantly negatively related to levels of foreign direct investment. As a result, it would be in societies' interests to avoid circumstances that enhance interstate conflicts, because those make the country less attractive for investment. The countries listed above are likely to experience a decrease in income growth and foreign direct investment accordingly.

A question forcing itself upon the reader is which factors countries, that experience high levels of violence and protests, might have in common. There might be political institutions that enhance conflict by ethnic minority groups. It is interesting to note, that the initially mentioned conflicts all involve different ethnic groups, such as Crimean Tatars in the Ukraine or Berber groups in Arab countries. This suggests that the reason for those conflicts might be rooted in political underrepresentation of the involved groups, which leads them to voice their opinion outside of the political routine. Mueller (2003, p.296) states that "the stability within 


\section{Ethnic Group Representativeness}

the political process that is brought about by denying diverse minorities proportionate representation in the legislatures to some extent is offset by the decisions of alienated minorities to opt out of the normal political process." The act of opting out of the normal political process can result in minority groups being involved in violent conflict. According to this causal chain groups' political underrepresentation leads to violent conflict, this in turn leads to low income growth.

The problem statement for this paper is consequently whether political underrepresentation of ethnic minority groups leads to conflict of any nature, verbal or violent, initiated by those groups. I hypothesize that countries in which specified groups are relatively less represented in governments experience more conflict than countries in which groups are adequately represented. The underlying argument is that groups that are represented in government have a platform to voice their opinions and interests and can take part in shaping policies. They therefore do not experience the need to voice their opinions by means of violent conflict.

In the next part of this paper existing theories of representation and conflict are reviewed and combined to a theoretical framework. Subsequently the methodology and research design are elaborated on, giving details about the data sources and manipulations of data for all variables involved in the empirical analysis. This is followed by the main empirical results of the statistical assessment of the abovementioned hypothesis, presenting summary statistics, correlations and regression output. Afterwards the empirical analysis is reproduced with alternative dependent variables in order to test the robustness of the prior results. Thereafter a discussion examines the results, relates them to the theory and looks at possible flaws. Then the paper concludes with a summary of the main findings.

\section{Theoretical Framework}

Researchers such as Powell, Alonso and Ruiz-Rufino have analyzed the relation between representativeness, which depicts the degree to which ethnic groups are granted effective access to governments, and conflict. Conflict can significantly differ in severity, ranging from vocal protests over demonstrations to civil wars. In his book Contemporary Democracies Powell (1982) looks at the relation between social and economic environment and democratic performance in 29 democracies during the 1960s and 1970. The countries he includes are dispersed over all continents except Africa. One part of his analysis is on the relationship between party systems fractionalization in legislatures and violent political conflict. Party systems fractionalization describes the probability that two legislators belong to 


\section{Ethnic Group Representativeness}

different parties. It thus shows the process of different interest groups separating themselves from other interests, so that different parties represent different viewpoints on issues at hand. It is an approximate measure of the number of parties in a government. Powell uses the average number of riots and the average deaths by political violence per year as his measure for violence. By conducting regression analyses, he finds higher levels of conflicts in countries with relatively less parties. Assuming that linkages between parties and groups are strong, having more parties in a parliament means that more groups are represented and can influence decision-making. These groups then do not have the need to voice their opinion through violent conflict. The number of parties in a government therefore is a suitable determinant of representativeness. Neto and Cox (1997) argue that the effective number of parties in parliament (ENPP), which is the concept used in this paper's empirical analysis, is determined as a multiplicative function of the electoral system in a country and the country's social heterogeneity. The ENPP is a concept that measures the number of parties in a country, while weighing all parties according to their relative strength (Mueller, 2003). The authors' data consists of elections during the 1980s in 54 countries. By conducting crosssectional regressions they validate their hypothesis. They find that the effective number of legislative parties on the seats level, ENPS, is significantly determined by the strength of the electoral system and by the effective number of parties on the votes level, ENPV, which in turn is determined by the ethnic heterogeneity of a country and an interaction term of the effective number of ethnic groups in a country and the median legislator's district magnitude. Following the argumentation given above the hypothesis arises that parliaments with a higher effective number of parties are more representative of ethnic minority groups and thus have a lower level of conflict in the country at hand. Powell (2004) alerts that there can be too many parties in a parliament, which would lead to high coordination costs and the potential for vote-seat disproportionality. This can potentially weaken the explanatory power of the effective number of parties and the effect on conflict initiated by ethnic minority groups.

According to Duverger's law (Duverger, 1954) there is a strong relationship between the number of parties in a country and the electoral system that is being used. While proportional electoral systems prove to bring about more parties, plurality rule single-member district systems often result in two-party competition. Lijphart (1990) supports Duverger and argues that a higher degree of proportionality of an electoral system allows for more new and small parties and will thus produce more parties. As described above, more parties are expected to reduce the amount of conflict in a country. This relation leads to electoral systems being suitable as another determinant of representativeness. In his 1981 paper Party Systems and Political Systems Performance: Voting Participation, Government Stability and Mass Violence in Contemporary Democracies Powell examines the hypothesis of a relation 


\section{Ethnic Group Representativeness}

between electoral system and conflict by looking at 28 democracies. He analyzes the relationship between party system types, which he classifies as aggregative majority, responsible majority or representative, and political performance, of which violence is one indicator. His standardized regression analysis finds that majority electoral systems are related to higher levels of violent conflict. On the contrary, proportional electoral systems seem to be successful in containing violence. The reasoning suggests that while in a proportional system, ethnic minorities or more specifically the parties that they associate themselves with, are represented proportionally to their share of the electoral franchise, in majority systems they could not gather enough votes to enter the parliament and are thus underrepresented in governments. Looking at the representation of women in parliament, Matland and Studlar (1996) claim that women are better represented in proportional electoral systems than in plurality rule systems with single-member districts. They argue that a contagion effect forces parties to represent women if another party does so, which is more likely the more parties there are, as is the case in proportional systems. They support their hypothesis by looking at the two cases of Norway and Canada, which both have multiparty systems. The same contagion effect might be present when looking at the representation of different ethnic groups in parliaments. This argumentation gives another justification for using the type of electoral system as a relevant determinant of the representativeness of groups. The theory yields the hypothesis that more proportional electoral systems lead to better representation of ethnic minority groups and are thus correlated with lower levels of conflict.

After assessing Lijphart's argumentation, Alonso and Ruiz-Rufino (2007) argue that the mere possibility for minority groups to be represented in governments, determined by the choice of electoral system and the effective number of parties, is not the deciding factor influencing levels of conflict, but the actual representation of those groups in parliaments. Only if ethnic minority groups are actually occupying seats in parliament, they can voice their opinion and influence political decision-making. The authors therefore look at the share of seats that ethnic parties hold in parliaments as their independent variable. Their dependent variables are scores on indices of protests and rebellion initiated by ethnic groups, which they take from the Minorities at Risk dataset (Minorities at Risk Project [MAR], 2009). They find a significant negative relationship between the share of seats and protest and rebellion scores in their sample of sixteen countries of the former Soviet Union between 1990 and 2000. The empirical analysis in this paper therefore takes the share of seats of minority groups in parliament as a third determinant of representativeness. A higher share of seats held by ethnic parties is expected to be related to lower levels of conflict in countries. However this relation should only hold if the share of seats of ethnic parties is adequate relative to the share that ethnic minority groups hold of the country's population. This argumentation relates 


\section{Ethnic Group Representativeness}

to the concept of proportional representation. If an ethnic group holds a share of seats that is relatively lower than its share of the population, the ethnic group is underrepresented and might voice its opinion through violent conflict. Creating a ratio of the share of seats divided by the share of population captures the argumentation at hand. The resulting hypothesis is that the higher this ratio is, the lower the level of conflict is expected to be.

Figure 1 shows the relationships that the theory predicts between the above mentioned variables. The Effective Number of Parties should increase representativeness. Equally, a more proportional electoral system and a higher share of seats for ethnic parties relative to the ethnic groups' share of the population increase representativeness. Higher representativeness in turn decreases the amount of conflict initiated by ethnic minority groups to be taking place in a country, which should lead to higher income growth. As can be seen above, the three determinants of representativeness used here can theoretically be interrelated, such as more proportionate electoral systems leading to a higher number of parties and to more ethnic parties being represented in parliament. The possibility of multicollinearity is accounted for in the data analysis. Comparison of the strength of existing relationships shows which of the three determinants entails most explanatory power. The argumentation yields the following research questions, which will be tested by means of an empirical analysis:

- Does a relation between representativeness of ethnic minority groups and conflict exist?

- Do the hypothesized signs of the relations between the individual determinants of representativeness and conflict hold?

- Which determinant of representativeness is the best predictor of conflict?

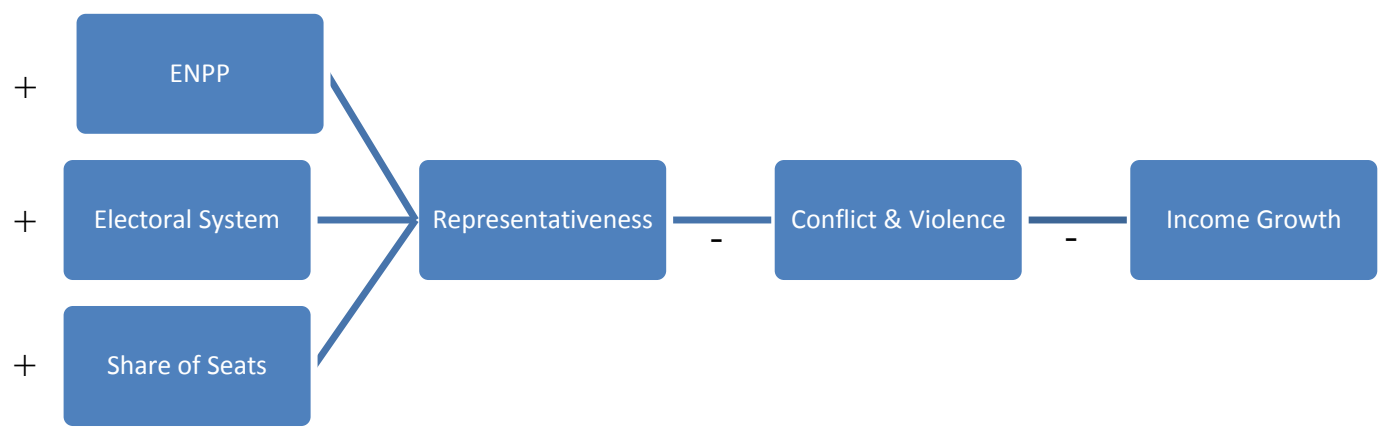

Figure 1. Conceptual Model

This paper makes no attempt to evaluate the ethical desirability of violent conflict. As pointed out in the introduction, violence is assumed to decrease foreign direct investment and thus income growth. Violence can however also be included in revolutions that overthrow governments. Although this might decrease investment in the short run, it is possible that the 


\section{Ethnic Group Representativeness}

standard of living of a population is improved in the long run. Revolutions can free citizens from oppression by dictators and from disregard of human rights. The analysis at hand will limit itself to examine the influence of violent conflict on income growth and not look into potential positive long-run effects for society and the standard of living.

The addition to existing knowledge provided by this research consists of support for the literature on the relation between violence and economic prosperity. An understanding of the underlying reasons for political violence can lead to more insights into the relationship with economic growth. The potential cause for high levels of violence is hypothesized to lie in a low level of representation of ethnic minorities. Assessing which determinant of representation of ethnic minorities has the strongest influence on violence yields potential policy design suggestions. Countries that are in a landslide phase and can redesign their political setup are in a position to influence their conflict potential and achieve higher income growth. This profound intrusion into a country's political setup might however only be attainable in the long run. It needs to be supported by the country's citizens and its decisionmakers. Furthermore it might not be desirable and desired in every country. The implications of the research at hand are thus of a rather theoretical, as opposed to a practical, nature.

\section{Methodology}

The remainder of this paper is concerned with the empirical test of the theory formulated above. Ordinary least squares regressions will be used to find out whether a statistical relationship between representativeness and conflict exists. The use of OLS regression is justified, due to the necessary assumptions of linearity, independence, equal variance and normality being met. The data used in those regressions has been collected from various databases. This induces the potential of mismatch between sources. This problem will be addressed in the discussion of the paper. Following the Comparative Political Data Set by Armingeon, Knöpfel, Weisstanner, Engler, Potolidis and Gerber of the University of Bern (2013), data on 52 countries has been collected. The sample includes 29 OECD member states, 28 member states of the European Union, 21 countries that are members of both of those groups and 15 countries that are members of neither of those groups. 27 countries, about half of the sample, are post-communist countries of Eastern Europe. A full list of countries in the sample can be found in the appendix. Due to low variation in variables such as electoral system and protest and rebellion scores and due to a lack of availability of timeseries data on variables such as the political rights index, the regression analyses will only be of a cross-section type. All variables present averages of data points for the years 2004 to 2006. This time frame was chosen due to data on protest and rebellion only being available 


\section{Ethnic Group Representativeness}

for 2004 to 2006 (MAR, 2009). Although time-series data might yield more insights into the relationship between representation of and conflict initiated by ethnic minority groups, the collection of appropriate data, goes beyond the scope of this thesis, due to time and budget constraints. The following paragraphs elaborate on data sources and manipulations for all variables involved in the empirical analysis of the theory.

\subsection{Independent variables}

As outlined in the theoretical framework, three different variables are examined as potential determinants of representativeness. The first one is the effective number of parties in parliaments on a seats level. Data is taken from the Comparative Political Data Set (Armingeon et al., 2013). This continuous variable is calculated according to a formula initially proposed by Laakso and Taagepera (1979). They use the Rae index to obtain

$E N P P=\frac{1}{1-R a e}$ with $r a e=1-\sum_{i=1}^{n} T^{2}$. The data source was missing several values, with this problem being especially pronounced for the set of post-communist countries. Missing values were therefore linearly interpolated before taking the average of the years 2004 to 2006 and then analyzing the data empirically.

The second determinant of representativeness is the electoral system used in a country. Using data from the IDEA database (International Institute for Democracy and Electoral Assistance [IDEA], 2010) a distinction between three different types of electoral systems is being made. Countries can use either a voting system following plurality or majority decision rules, or a proportional representation system, or a mix of the latter two. In a plurality rule system the candidate or party with the highest number of votes wins the election, in a majority rule the winner has to have the support of more than half of the electorate. In a system of proportional representation the goal is to maximize vote-seat proportionality, so that the preferences of all citizens are presented in the government as direct as possible. Mixed systems contain characteristics of both majority and proportional systems (Mueller, 2003). The electoral system enters the analysis as a dummy variable with nominal categories, using a plurality/majority system as the base line. This simplifies the interpretation of regression results. In order to check whether it is the electoral system or the specific electoral type that influences conflict, the electoral type is taken as another determinant, using data from the IDEA database (IDEA, 2010). A distinction between seven different electoral types is being made. Countries can use a first-past-the-post (FTPT) type, an alternative vote type (AV), a two-round type (TRS), a list proportional representation type (List PR), single transferable votes (STV), a mixed member proportional type (MMP) or a parallel type. The first three of those systems are used solely in plurality or majority rule electoral systems, while the MMP and the parallel type have characteristics of both plurality 


\section{Ethnic Group Representativeness}

and proportional representation systems (Mueller, 2003). Although other electoral types do exist, they are not represented in the sample of countries used in the analysis at hand. For this categorical dummy variable the electoral type of parallel voting is used as the base line.

The percentage share of seats of ethnic parties in parliament is taken from the Comparative Political Data Set (Armingeon et al., 2013). The source categorizes parties according to the time-invariant classification by Lane, McKay and Newton (1997). A list of parties classified as ethnic for the given sample of 52 countries can be found in the appendix. The Comparative Political Data Set only gives data for parties that reached at least two percent of the votes in an election in the time frame being examined. This provides a limitation for the analysis, since parties obtaining less than two percent of all votes could nevertheless give some form of influence on political decision-making to ethnic minorities and thus reduce conflict. Data for the analysis at hand was obtained by summing the seat shares of all ethnic parties in a country per year and then taking the average for the years 2004 to 2006. An effect on conflict should only be observable according to the formulated theory, if the share of seats of ethnic parties is low relative to the share that ethnic minorities hold of the country's population. Only then an underrepresentation is given. Therefore data on the share of the population held by ethnopolitical groups is taken from the Minorities at Risk dataset (MAR, 2009) in order to create a ratio of both shares. According to the source's classification, groups qualify as ethnopolitical if:

"Membership in the group is determined primarily by descent by both members and non-members... . Membership in the group is recognized and viewed as important by members and/or non-members. The importance may be psychological, normative, and/or strategic. Members share some distinguishing cultural features, such as common language, religion and customs. One or more of these cultural features are practiced by a majority of the members of the group. The group has at least 100,000 members or constitutes one percent of a country's population." (MAR, 2009, codebook, p.1).

See the appendix for a list of groups meeting these criteria. Data for the analysis at hand was obtained by summing the population shares for all groups per country for each year and then taking the average of the years 2004 to 2006. Due to the classification requirements for both ethnic parties and ethnopolitical groups, there are several observations that have zero values for both variables. This is especially pronounced in the variable of the share of seats of ethnic parties. Therefore the ratio of the share of seats divided by the share of the population held by ethnopolitical groups is calculated as share ratio $=\frac{\text { share of seats }+1}{\text { share of population }+1}$. While this 


\section{Ethnic Group Representativeness}

changes the numerical values of the ratio observations, it leaves the interpretation of the coefficient unchanged. A higher ratio still signifies a more proportional representation. A potential bias is induced due to the thirteen observations for which both variables included in the ratio have zero values. These observations now have a ratio of one, meaning perfect representation. The bias should however not be overstated, because the zero values are caused by the classification requirements and do not appear randomly. Not representing an ethnic party in parliament if the associated ethnic group makes up only a negligible part of the population is appropriate and can be regarded as proportional representation. Including dummy variables for missing observations on the share of seats, the share of population or both does not significantly change the results of the empirical analysis.

A possible bias in the empirical results might be induced due to potential mismatch of classifications between the different data sources. The linkage between the ethnic groups analyzed in the Minorities at Risk dataset (MAR, 2009) and the parties classified as ethnic by the Comparative Political Dataset (Armingeon et al., 2013) is rather low. A more coherent database is however not available at the moment and collection of new data is beyond the scope of this paper. This obstruction will be explained at more length in the discussion part of this paper.

\subsection{Dependent variables}

The dependent variables used in this paper's empirical analysis are the protest and rebellion scores taken from the Minorities at Risk database (MAR, 2009). The database looks at ethnopolitical groups, a list of which can be found in the appendix, and classifies any violent or non-violent conflict initiated by this group on an index according to its severity. Protests are scaled on a range from zero to five. A zero indicates no reported protest. A one stands for verbal opposition and verbal requests for independence. A two indicates symbolic resistance, meaning symbolic destruction of property or substantial political organizing. The bins three to five order demonstrations from being small to being large according to the amount of people participating. Small demonstrations, class three, occur seldom and have a highest total participation of 10,000 people. Medium demonstrations, class four have participation between 10,000 and 100,000 people, while large demonstrations, class five, have more than 100,000 people participating. (MAR, 2009).

The severity of rebellions is ordered on a scale from zero to seven. Zero, again, stands for none being reported. One stands for fewer than six events of political banditry or sporadic terrorism, while two stands for more than six events related to campaigns of terrorism. A three indicates local rebellions, which are violent efforts to gain power. Scores four to six 


\section{Ethnic Group Representativeness}

concern guerilla activity. Small-scale guerilla activity, class four, has fewer than 1,000 armed participants, less than six armed attacks in a year and those attacks only taking place in small areas of the country. Large-scale guerrilla activity, class six, on the contrary includes more than 1,000 armed fighters, more than six events per year and a large area of the country being affected. Intermediate guerrilla activity, class five lies in the middle of this spectrum. Class seven indicates a civil war. (MAR, 2009). Data for the empirical analysis was obtained by averaging the sum of protest and rebellion scores respectively connected to all ethnopolitical groups in each country in the time frame of 2004 to 2006.

\subsection{Control variables}

In order to control for possible effects of income on conflict, GDP per capita based on purchasing power parity was included as control variable, with data taken from the Worldbank statistics database (Worldbank, 2014a). A high income is expected to decrease conflict by going hand in hand with sound political institutions that guarantee adequate representation of the population. High income can further lead to higher police presence and court systems, which are likely to reduce incentives to take part in violent conflict.

As a further control variable, the Freedom House political rights index (Freedom House, 2014) is included, following Alonso and Ruis-Rufon (2007). For this index, each country is given a ranking on a scale from one to seven. On this scale one indicates the highest level of political rights being present, while a seven is assigned to the countries with the relatively lowest levels of political freedom. Countries with higher levels of political freedom are expected to experience lower levels of conflict.

\section{Main Empirical Results}

\subsection{Descriptive Statistics}

Table 1 presents summary statistics for the dependent variables used in the empirical analysis. Both the protest and the rebellion indices do not approach high levels in the sample of 52 countries used in the research at hand. With an average score of 3.33 on the Minorities at Risk project's protest index, both Latvia and New Zealand experience the highest average level of protest during 2004 to 2006. The summary shows that the countries did not, on average, experience more severe conflict than verbal opposition. Almost none of the countries in the sample experienced an event that qualifies to be on the rebellion index. The highest score on the scale from zero to seven is reached by Ireland, having an average score of one in the years 2004 to 2006. 


\section{Ethnic Group Representativeness}

Table 1. Summary statistics dependent variables

\begin{tabular}{lcccccl}
\hline Variable & Mean & Median & Maximum & Minimum & Std. Dev. & Observations \\
\hline Protest & 0.899087 & 0.500000 & 3.333333 & 0.000000 & 1.004294 & 52 \\
Rebellion & 0.097465 & 0.000000 & 1.000000 & 0.000000 & 0.237378 & 52 \\
\hline
\end{tabular}

Table 2 gives the summary statistics for the main independent variables used in the empirical analysis. The majority of countries in the sample uses proportional representation as their electoral system.

Table 2. Summary statistics main independent variables

\begin{tabular}{lcccccl}
\hline Variable & Mean & Median & Maximum & Minimum & Std. Dev. & Observations \\
\hline Electoral Syst. & 2.060000 & 2.000000 & 3.000000 & 1.000000 & 0.619743 & 50 \\
Electoral Type & 4.280000 & 4.000000 & 7.000000 & 1.000000 & 1.565 .443 & 50 \\
ENPP & 3.724072 & 3.700004 & 9.119000 & 1.000 .000 & 1.489 .635 & 50 \\
Share Ratio & 0.920978 & 0.956938 & 1.078 .000 & 0.498753 & 0.105312 & 50 \\
\hline
\end{tabular}

Consequently the electoral type used by most of the countries is a list proportional representation voting type. The effective number of parties in parliaments differs greatly in the sample of countries with the median lying at around 3.7 effective parties in parliament. For this variable two outliers were excluded from the analysis, so that the number of observations reduces to 50 instead of 52 countries. The outliers came about due to linear interpolation of missing data, which resulted in exaggerated trends for Belarus and the Kyrgyz Republic due to a minimal amount of data being available for the process of linear interpolation. The share ratio, defined as the average share of seats that all parties classified as ethnic hold in a countries parliament in 2004 to 2006 divided by the average share of the population made up by ethnopolitical groups in a country in the same time frame, has a mean of 0.921 , saying that the average country represents ethnic groups in a rather proportional way.

In their paper on the effect of the share of seats of ethnic parties on conflict, Alonso and Ruiz-Rufino (2007) look at a sample of only post-communist countries. Since postcommunist countries make up about 52 percent of the sample of countries used in the empirical analysis at hand, it is important to see whether the results of the analysis are driven by those countries. An independent sample t-test compares the means of both groups of countries, post-communist and not post-communist, when looking at the two dependent variables protest and rebellion. Table 3 reveals that there is no significant difference in the 


\section{Ethnic Group Representativeness}

means of the protest and rebellion scores between both country groups. Therefore the differentiation between country groups can be disregarded for the empirical analysis.

Table 3. Independent samples t-test of post-communist versus not post-communist countries regarding protest and rebellion

\begin{tabular}{llrrllclc}
\hline Variable & & \multicolumn{9}{c}{$\begin{array}{c}\text { Std. } \\
\text { P.-C. }\end{array}$} & $\mathbf{N}$ & Mean & Deviation & $\begin{array}{c}\text { Std. Error } \\
\text { Mean }\end{array}$ & t & df & $\begin{array}{c}\text { Sig. } \\
\text { (2-tailed) }\end{array}$ \\
\hline Protest & 0 & 25 & .8467 & 1.06520 & .21304 & -.359 & 50 & .721 \\
& 1 & 27 & .9476 & .96227 & .18519 & & & \\
Rebellion & 0 & 25 & .0956 & .23653 & .04731 & -.055 & 50 & .956 \\
& 1 & 27 & .0992 & .24265 & .04670 & & & \\
\hline
\end{tabular}

\subsection{Correlations and Scatterplots}

In order to gain an initial insight into whether the hypothesized relationships hold, a correlation table is constructed, examining the correlations between the main dependent and independent variables. As can be expected, there is a strong and significant correlation between the electoral type and the electoral system used in a country. This is not surprising since several electoral types can only reasonably be used in certain electoral systems. An example is the list proportional representation electoral type, which can only be applied in a proportional representation system. Furthermore there is a significant negative correlation between the share ratio and the effective number of parties. This is reasonable because one party having a higher share of the total amount of seats in a parliament means that there are fewer seats left for other parties, holding the total number of seats constant. Thus the total number of parties is likely to decrease. The hypothesis of a higher share ratio leading to less conflict seems to be confirmed when looking at protest as the dependent variable. There is a highly significant negative correlation between the two variables. The correlation of the share ratio with rebellion on the other hand is neither significant nor of the right sign. This suggests that ethnic minority groups' response to underrepresentation is not of a highly violent nature that would qualify for the rebellion index. Citizens seem to rather respond by means of protests, such as demonstrations of different sizes. While Table 4 shows negative correlations of the effective number of parties with both protest and rebellion, these are not significant. A potential reason for this is the low linkage between ethnopolitical groups and parties classified as ethnic by Lane, McKay and Newton (1997). A more elaborate explanation of this problem is presented in the discussion of this paper. An interpretation of the correlations of electoral systems and electoral types with the dependent variables is rather challenging. This is because the electoral types and systems are not necessarily ordered in a way that increases with the degree of proportionality in the classification index of 


\section{Ethnic Group Representativeness}

the IDEA database (IDEA, 2010). Therefore one should abstain from interpreting the correlation coefficients.

Table 4. Correlations of main dependent and independent variables

\begin{tabular}{lcccccc}
\hline Indicant & $\mathbf{1}$ & $\mathbf{2}$ & $\mathbf{3}$ & $\mathbf{4}$ & $\mathbf{5}$ & $\mathbf{6}$ \\
\hline Electoral System & 1 & & & & & \\
Electoral Type & $0.944^{* *}$ & 1.000 & & & & \\
ENPP & 0.109 & 0.055 & 1.000 & & & \\
Share Ratio & 0.056 & 0.092 & $-0.285^{*}$ & 1.000 & & \\
Protest & 0.051 & 0.008 & -0.052 & $-0.383^{* *}$ & 1.000 & \\
Rebellion & -0.059 & 0.017 & -0.194 & 0.030 & $0.324^{*}$ & 1.000 \\
\hline Note. ${ }^{* *} \mathrm{p}<.01^{*} \mathrm{p}<.05$ & & & & &
\end{tabular}

An alternative is to examine whether there is a significant difference in the means of each countries score on the protest and rebellion indices, when grouping countries according to their electoral system and electoral type. This is done by using an ANOVA analysis as presented in tables 5 and 6 . Table 5 shows that there is no significant difference in protest and rebellion score means between countries differing in their use of electoral systems. Table 6 shows a significant difference in mean protest scores between countries using different electoral types. The significance vanishes when looking at means of the rebellion scores of countries.

Table 5. ANOVA analysis of electoral system on protest and rebellion

\begin{tabular}{llrrrrr}
\hline Variable & \multicolumn{1}{c}{ Source } & Sum of Squares & $\mathbf{d f}$ & Mean Square & $\mathbf{F}$ & Sig. \\
\hline Protest & Between Groups & 3.106 & 2 & 1.553 & 1.575 & .217 \\
& Within Groups & 48.333 & 49 & .986 & & \\
& Total & 51.439 & 51 & & & \\
\multirow{5}{*}{ Rebellion } & Between Groups & .022 & 2 & .011 & .189 & .829 \\
& Within Groups & 2.852 & 49 & .058 & & \\
& Total & 2.874 & 51 & & & \\
\hline
\end{tabular}

The correlations in table 4 are supported by scatterplots of both the effective number of parties and the share ratio against both protest and rebellion. The best fit lines show a negative relation between ENPP and both dependent variables. The relation is however not strong and largely influenced by the high amount of zero scores on both indices. 


\section{Ethnic Group Representativeness}

Table 6. ANOVA analysis of electoral type on protest and rebellion

\begin{tabular}{llrrrrr}
\hline Variable & \multicolumn{1}{c}{ Source } & Sum of Squares & $\mathbf{d f}$ & Mean Square & $\mathbf{F}$ & Sig. \\
\hline Protest & Between Groups & 10.430 & 6 & 1.738 & 1.908 & .100 \\
& Within Groups & 41.009 & 45 & .911 & & \\
& Total & 51.439 & 51 & & & \\
\multirow{3}{*}{ Rebellion } & Between Groups & .483 & 6 & .081 & 1.517 & .194 \\
& Within Groups & 2.390 & 45 & .053 & & \\
& Total & 2.874 & 51 & & & \\
& & & & &
\end{tabular}

The scatterplot of the share ratio against the protest scores exhibits a strong negative relationship, which is supported by the significant negative correlation between the two variables. Just as the correlation between the share ratio and the rebellion scores is positive and insignificant, the scatterplot entails a slightly positively sloped best fit line. There is a highly likely bias from the high amount of zero scores on the rebellion score.
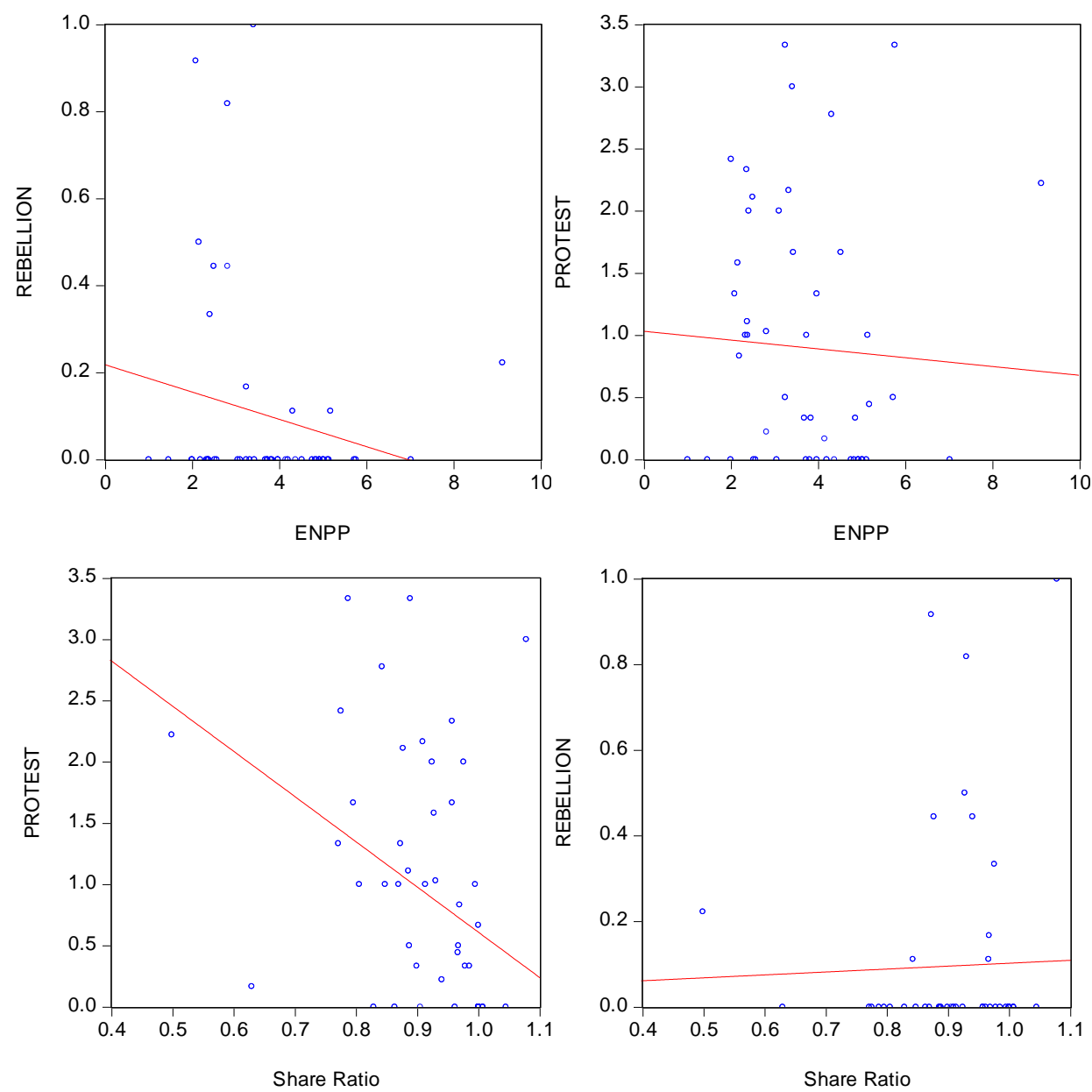

Figure 2. Scatterplots of ENPP and share ratio against protest and rebellion, including best fit lines. 


\section{Ethnic Group Representativeness}

\subsection{Regression Analysis Output}

The next step in analyzing whether the hypothesized relationships between the determinants of representativeness and conflict hold is to conduct ordinary least squares regression analyses with the variables involved. The final models incorporating all variables for this purpose are as follows, with the first model using electoral systems and the second model using electoral types:

1. $E C_{i}=\beta_{0}+\beta_{1} E N P P_{i}+\beta_{2} E_{-}$Mixed $_{i}+\beta_{3} E S_{-} P R_{i}+\beta_{4}$ Seats $_{\text {Population }}-$ Ratio $_{i}$

$$
+\beta_{5} G D P_{i}+\beta_{6} \text { PoRi }- \text { Index }_{i}+e
$$

2. $E C_{i}=\beta_{0}+\beta_{1} E N P P_{i}+\beta_{2} E T_{-} A V_{i}+\beta_{3} E T_{-} F P T P_{i}+\beta_{4} E T_{-} L i s t P R_{i}+\beta_{5} E T_{-} M M P_{i}+\beta_{6} E T_{-} S T V_{i}$

$$
\begin{aligned}
& +\beta_{7} \text { ET TRS }_{i}+\beta_{8} \text { Seats }- \text { Population }- \text { Ratio }_{i}+\beta_{9} G D P_{i}+\beta_{10} \text { PoRi }- \text { Index }_{i} \\
& +e
\end{aligned}
$$

Where:

$\mathrm{EC}_{\mathrm{i}}=$ Ethnic conflict index (Protest, Rebellion) for country $\mathrm{i}$

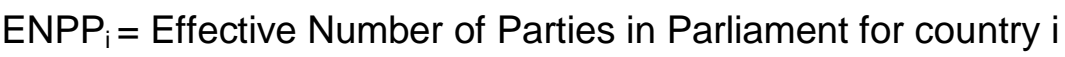

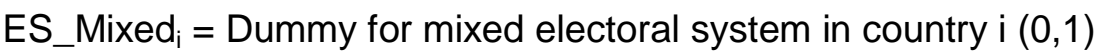

$E S \_P R_{i}=$ Dummy for proportional representation electoral system in country $i(0,1)$

$E T \_A V_{i}=$ Dummy for alternative voting electoral type in country $i(0,1)$

ET_FPTP ${ }_{i}=$ Dummy for first-past-the-post electoral type in country $\mathrm{i}(0,1)$

$E T \_L i s t P R_{i}=$ Dummy for list proportional representation electoral type in country $i(0,1)$

ET_MMP ${ }_{i}=$ Dummy for mixed-member proportional electoral type in country $\mathrm{i}(0,1)$

$E T \_S T V_{i}=$ Dummy for single transferable vote electoral type in country $i(0,1)$

$E T_{-} T_{R S}=$ Dummy for two-round system electoral type in country $i(0,1)$

Seats-Population-Ratio ${ }_{i}=$ Share of seats of ethnic parties in parliament divided by share of the population held by ethnopolitical groups in country $\mathrm{i}$

$\mathrm{GDP}_{\mathrm{i}}=$ GDP per capita in country $\mathrm{i}$

PoRi-Index ${ }_{i}=$ Freedomhouse political rights index in country $\mathrm{i}$

Eight individual regressions have been conducted for each dependent variable, building up to the final models presented above. Table 7 presents the results for all regressions using the protest scores as dependent variable. Models one to four, in turn, look at the possible effects of the main determinants of representativeness. Models five and six examine all potential determinants except of the two control variables GDP and the political rights index together, only differing in using either the electoral system or the electoral type. Using both of these together would lead to biased results, due to the high multicollinearity between the two 


\section{Ethnic Group Representativeness}

shown in Table 4. Models seven and eight are the two final models, which again only differ in using either the electoral system or the electoral type. Both models add the control variables GDP per capita and the Freedom House Political Rights index. Table 8 shows the results of the same analyses being conducted with the rebellion scores as the dependent variable.

Model one in Table 7 shows a negative coefficient of the effective number of parties on the protest index score, as is expected from theory. However, the coefficient is not significant and the R-square of the regression is very low, suggesting that almost none of the variation in protest scores is explained by the number of parties in parliament only.

Model two shows that countries which use an electoral system of proportional representation experience less protest than countries which use plurality or majority electoral systems. This relation behaves as predicted by theory. Proportional representation systems aim at providing vote-seat proportionality, meaning that a party should get the same share of seats in parliament, as the share of votes it received in an election (Mueller, 2003). This leads to better representation of the opinions expressed by citizens during an election. Therefore, ethnic minorities should be able to more effectively influence political decision-making by making their voices heard in a proportional representation system. However, as can be seen in Table 7, the coefficient on the proportional representation system is not significant and the $\mathrm{R}$-square of the regression is very low.

Model three looks at the effect of different electoral types on protest scores. While some of the expected relationships hold; the plurality rule electoral types first-past-the-post and alternative vote experience higher levels of protest, whereas countries using the list proportional representation type experience lower levels of protest, only one coefficient among the different electoral types is significant. Countries using mixed member proportional systems (MMP) suffer from significantly more protest than countries using a parallel electoral type. In an MMP system both a proportional and a majority voting system are used, with the proportional system aimed at compensating any disproportionality that resulted from the majority system. An example of a country using an MMP system is Germany, where it is used for federal level elections. MMP systems are used in order to counterbalance the unwanted parts of the "extremes" of purely proportional and purely majoritarian systems. They are intended to create stable party systems (Shugart \& Wattenberg, 2001). Therefore it is surprising to find significantly higher protest scores in countries using MMP systems. An indepth look at the data reveals that the finding depends on the inclusion of New Zealand in the empirical analysis. New Zealand uses an MMP system and experiences the highest level of protest in the sample, along with Latvia. Excluding New Zealand from the analysis renders 


\section{Ethnic Group Representativeness}

the coefficient insignificant. Using electoral types as opposed to electoral systems adds a high amount of explanatory power to the regression, as can be seen from the increased adjusted R-square. This suggests that not every electoral type falling under the heading proportional representation is able to yield adequate representation of ethnic groups and thus effectively decrease conflict.

Model four examines the effect of an increase in the share of seats of ethnic parties in a parliament relative to the share of a country's population held by ethnopolitical groups on protest scores. The coefficient on the share ratio is highly significant, of the expected sign and of a high magnitude. This implies support for the significant negative correlation in Table 4 and the highly articulate scatterplot in Figure 2.

Model five examines the effect of all three determinants of representativeness, namely the effective number of parties in parliament, the electoral system and the share ratio, on protest scores. While all variables have the expected coefficients, only the coefficient on the share ratio is significant and even increases in magnitude.

Model six equals model five, solely replacing the electoral system by the electoral type. The share ratio remains significant and further increases in magnitude. As in model three the mixed member proportional electoral type comes with significantly higher protest scores than the parallel electoral type. Furthermore countries using a single transferable vote electoral type have a significantly higher amount of protest than countries using the parallel electoral type. This is surprising, because the electoral type of single transferable vote is aimed at creating proportional representation (Mueller, 2003). Due to only two countries in the sample using a system of single transferable voting, the coefficient is however highly sensitive to potentially unobserved country characteristics. Just as when moving from model two to model three, moving from model five to model six comes with an increase in R-square, suggesting that the electoral type has more explanatory power than the electoral system.

Models seven and model eight equal models five and six, but add the control variables of GDP per capita and the Freedom House index of political rights. In both models a higher political rights index score significantly but only slightly reduces the protest score. This is contradictory to expectations, since a higher score on the political rights index signifies a lower level of political rights. The share ratio remains highly significant and increases in magnitude even further. Model eight again shows a significant effect of using a mixed member proportional electoral type on protest, but the magnitude and significance level of 


\section{Ethnic Group Representativeness}

the coefficient decrease. Including the control variables in the regression highly increases the explanatory power of the regression, as can be seen from the increase in the R-square.

As in Table 7, Table 8 shows that all models including electoral types have far more explanatory power than the models using electoral systems. However, the overall lower Rsquares in Table 8 suggests that representativeness cannot explain as much of the variation in rebellion scores as it can explain of the variation in protest scores. Another striking difference when using rebellion as dependent variable instead of protest is that there are far less significant coefficients in the models. The share ratio, that was consistently significant in Table 7, loses all of its significance, largely decreases in magnitude and does not consistently have the expected sign. The only variable that is significant in explaining rebellion scores is the single transferable vote electoral type. Countries using this electoral type experience more rebellion than countries using a parallel electoral type. As explained above, this relationship is likely to be highly sensitive to unobserved country characteristics. While the effective number of parties in parliament has a negative effect on rebellion in all models, the proportional electoral system and proportional electoral types do not reliably have the sign that is expected from theory.

\subsection{Robustness of the Share Ratio Coefficient}

The share ratio is a consistently strong predictor of protest in the preceding empirical analysis. In order to assess whether the coefficient is robust across other model specifications, it is tested further in this paragraph. Table 9 shows that the significance of the ratio of the share of seats of ethnic parties in parliament divided by the share of the population held by ethnopolitical groups is robust across models that exclude outliers in the data. The basic model is the same as model seven in Table 7. The second and third columns replicate the same model, but exclude outliers in the share of population of ethnopolitical groups. This is done because the average summed population share of all ethnopolitical groups in the timeframe of 2004 to 2006 is larger than 100 percent in Bosnia-Herzegovina and close to 60 percent in Kazakhstan. This indicates that the groups in these countries cannot be regarded as ethnic minorities, which are the object of the theory presented in this paper. 


\section{Ethnic Group Representativeness}

Table 7. OLS regressions with dependent variable protest

\begin{tabular}{|c|c|c|c|c|c|c|c|c|}
\hline \multicolumn{9}{|l|}{$\begin{array}{l}\text { Dependent } \\
\text { Variable: }\end{array}$} \\
\hline \multicolumn{9}{|c|}{ Models } \\
\hline Variable & 1 & 2 & 3 & 4 & 5 & 6 & 7 & 8 \\
\hline $\bar{C}$ & $1.033638^{*}$ & $1.148148^{\star \star \star}$ & $0.801587^{\star *}$ & $4.301253^{\star \star \star}$ & $4.979778^{\star \star \star}$ & $5.072915^{\star \star \star}$ & $7.215852^{\star \star \star}$ & $6.772457^{\star \star \star}$ \\
\hline ENPP & -0.035424 & & & & -0.067321 & -0.027355 & -0.095388 & -0.050805 \\
\hline ES_Mixed & & 0.104377 & & & 0.197674 & & -0.036099 & \\
\hline ES_PR & & -0.440604 & & & -0.307341 & & -0.666573 & \\
\hline ET_AV & & & 1.198413 & & & 1.411097 & & 1.163278 \\
\hline ET_FPTP & & & 0.635913 & & & 0.424879 & & 0.372057 \\
\hline ET_List PR & & & -0.146873 & & & -0.165356 & & -0.344717 \\
\hline ET_MMP & & & $1.240079^{* *}$ & & & $1.282092^{\star *}$ & & $0.981384^{*}$ \\
\hline ET_STV & & & 0.698413 & & & $1.206284^{*}$ & & 0.994861 \\
\hline ET_TRS & & & -0.155754 & & & -0.259160 & & 0.212481 \\
\hline Seats- & & & & & & $-4.528775^{\star \star *}$ & $-5.183346^{\star \star *}$ & $-5.383512^{\star * *}$ \\
\hline \multicolumn{9}{|l|}{ Population } \\
\hline Ratio & & & & $-3.691953^{\star * *}$ & $-3.996070^{\star \star *}$ & & & \\
\hline GDP & & & & & & & $-8.21 E-06$ & $-9.91 E-06$ \\
\hline PoRi_Index & & & & & & & $-0.283749^{\star \star *}$ & $-0.238096^{* *}$ \\
\hline $\mathrm{R} 2$ & 0.002656 & 0.060390 & 0.202771 & 0.146354 & 0.212438 & 0.398260 & 0.375870 & 0.487403 \\
\hline Adjusted R2 & -0.018122 & 0.022039 & 0.096474 & 0.129282 & 0.142432 & 0.280848 & 0.288782 & 0.355968 \\
\hline
\end{tabular}

Note. ${ }^{* *} p<0.01{ }^{* *} p<0.05{ }^{*} p<0.1$

Table 8. OLS regressions with dependent variable rebellion

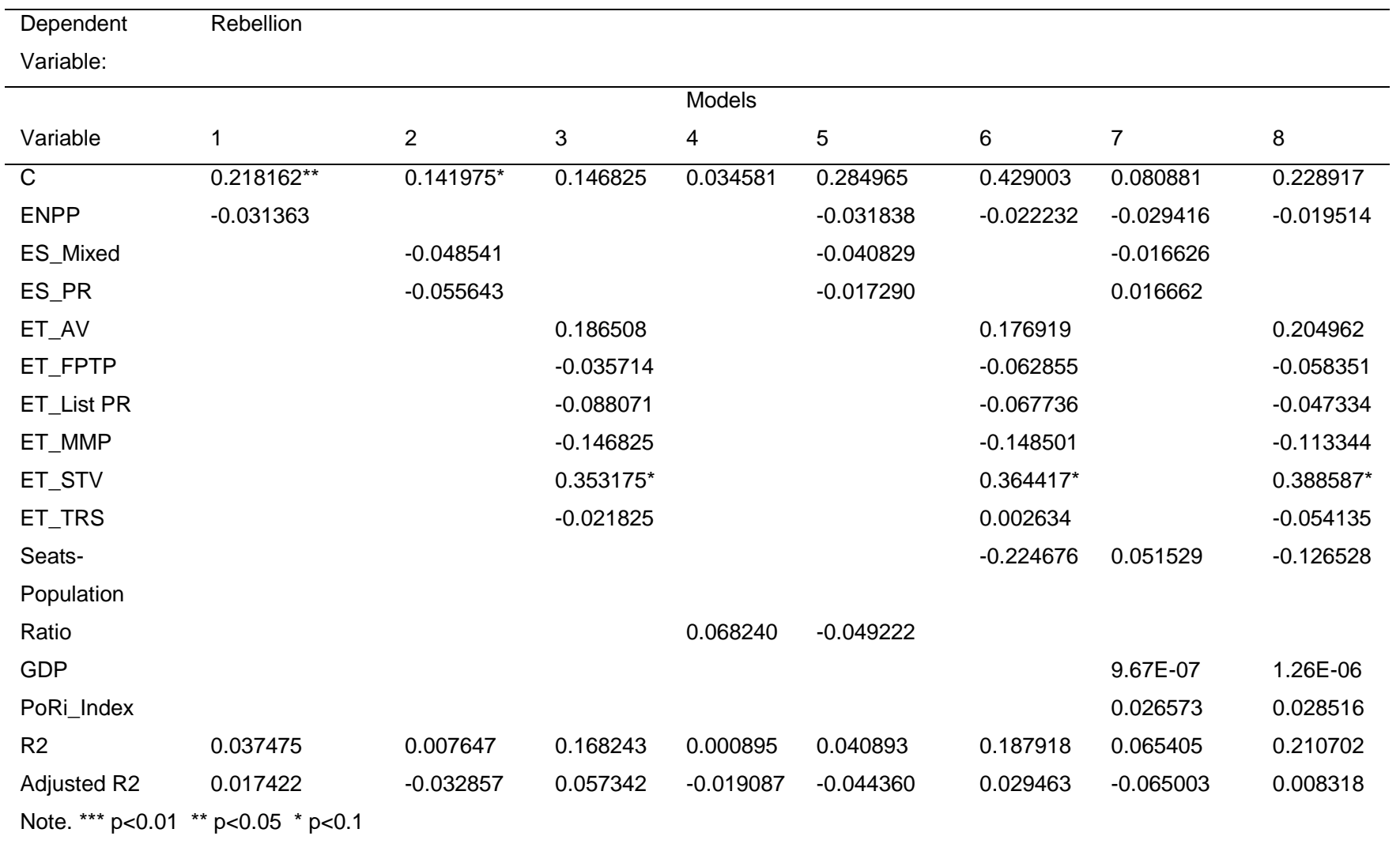




\section{Ethnic Group Representativeness}

The second column of Table 9 therefore excludes all countries with an average summed population share higher than 50 percent. The third column excludes all individual groups that have a population share higher than 30 percent before calculating the average summed population share of all ethnopolitical groups in the country. Two groups are excluded through this process; the Muslims in Bosnia-Herzegovina, making up almost 50 percent of the population, and the Serbs in Bosnia-Herzegovina, making up about 37 percent of the population.

Table 9 shows that the coefficient of the share ratio's effect on the protest index score remains significant, of the right sign and of high magnitude. This suggests that the share ratio is a robust determinant of representativeness. However, it should be noticed that the Rsquare of the regressions in column two and three drops relative to the basic model, showing that the explanatory power of the model decreases.

Table 9. OLS regressions testing the robustness of the seat share - population share ratio

\begin{tabular}{|c|c|c|c|}
\hline Dependent Variable: & Protest & & \\
\hline Variable & Basic model & Adjusted for $t$ & Adjusted for i \\
\hline $\mathrm{C}$ & $7.215852^{\star \star \star}$ & $6.611451^{\star \star \star}$ & $5.713983^{\star \star \star}$ \\
\hline ENPP & -0.095388 & 0.047200 & 0.013074 \\
\hline ES_Mixed & -0.036099 & -0.072045 & 0.048205 \\
\hline ES_PR & -0.666573 & -0.612867 & -0.576038 \\
\hline Seats-Population Ratio & $-5.183346^{\star \star \star}$ & $-5.266849^{\star \star \star}$ & $-4.027651^{\star \star}$ \\
\hline GDP & $-8.21 E-06$ & $-7.26 \mathrm{E}-06$ & $-1.12 \mathrm{E}-05$ \\
\hline PoRi_Index & $-0.283749^{\star \star \star}$ & $-0.188449^{*}$ & $-0.265153^{\star \star}$ \\
\hline$R^{2}$ & 0.375870 & 0.290545 & 0.260909 \\
\hline Adjusted $R^{2}$ & 0.288782 & 0.191551 & 0.157781 \\
\hline
\end{tabular}
Note. ${ }^{* * *} p<0.01{ }^{* *} p<0.05{ }^{*} p<0.1$

\section{Testing Robustness: Alternative dependent variables}

Protest and rebellion are not the only possible reactions to underrepresentation of ethnic minority groups. As was elaborated on above, there is a significant relation between representativeness and protest as a measure of conflict, while the relation cannot be observed if a rebellion index is used as measure of conflict. Members of ethnic minority groups might chose to emigrate if their interests are not represented in the country they live in. This reaction can be a sensible response in countries where other options, such as taking part in demonstrations, are highly criminalized and would result in charges to be paid or in 


\section{Ethnic Group Representativeness}

imprisonment. Therefore one can expect a decrease in net migration resulting from a decrease in representativeness. Another possible reaction to underrepresentation of ethnic groups would be a decrease in voter turnout. Members of ethnic minorities are likely to experience disenchantment with politics as a result of being underrepresented. If members of ethnopolitical groups are part of the electorate, voter turnout is expected to decrease with a decrease in representativeness. Performing statistical analyses with these alternative dependent variables is a reasonable test of the appropriateness and robustness of the determinants of representativeness used in this paper.

The above formulated theory predicts positive coefficients on the determinants of representativeness, namely on an increase in ENPP, on a relatively more proportional electoral system or type and on a higher ratio of share of seats of ethnic parties divided by share of population of ethnic groups. The results should however be handled with care, since they might be picking up effects that are not influenced by representativeness. One should be cautious when putting the dependent variables protest, rebellion, voter turnout and net migration on a continuum of the strength of the reaction to ethnic group underrepresentation. The reason for this is that the response chosen by ethnic minority group members might be influenced greatly by country characteristics and cultural factors, which are not accounted for in the empirical analysis.

Data on net migration is taken from the Worldbank statistics database (Worldbank, 2014b). Net migration is defined as the difference between the number of immigrants into and the number of emigrants out of a country. The Worldbank publishes estimates of net migration every five years. For the analysis at hand data reported for 2002 and 2007 is taken and linear interpolation is used to find the values for the years in between. Then the average of the years 2004 to 2006 is taken as estimate for the regression analysis. Data on voter turnout for parliamentary elections as a percentage of registered voters is extracted from the International Institute for Democracy and Electoral Assistance (IDEA, 2014). In the case of multiple elections in the time frame of 2004 to 2006, data shows the average voter turnout of those elections. If there were no elections in the time frame, average turnouts of the two closest elections, which mostly took place in 2003 and 2007, are taken.

An independent samples t-test of both net migration and voter turnout, classified into two groups of either post-communist or not post-communist countries, shows that there are significant differences in the means of both dependent variables, depending on which group a country belongs to. It is therefore sensible to include a post-communist country dummy into all regressions performed with those dependent variables. 


\section{Ethnic Group Representativeness}

Table 11 replicates the regressions of columns seven and eight in Tables 7 and 8 , only changing the dependent variable first to net migration and then to voter turnout. The output using the dependent variables protest and rebellion is given for comparison. While the regressions on net migration and voter turnout almost all have higher R-squares than the ones on protest and rebellion, the consistency of the significance patterns is not given anymore. The coefficient on the effective number of parties in parliament is significant in the first column. However, the coefficient is negative in all regressions on net migration and voter turnout, contradicting the theory that a higher number of parties leads to less emigration and to higher voter turnout through the channel of better representation. The coefficient of the share ratio is significant, but of the wrong sign in the regressions on net migration, given the definition of net migration as the total number of immigrants minus the total number of emigrants. Although the coefficient changes to the expected sign in the regressions on voter turnout, it loses its significance. The theory on representativeness predicts that the use of a first-past-the-post (FPTP) electoral type, as used in majority electoral systems, should result in higher conflict than using a parallel electoral type, due to crowding out small geographically evenly distributed parties and resulting in two-party competition, which means that small ethnic parties are less represented (Mueller, 2003). The coefficient on the FPTP electoral type contradicts the theory in the regression on net migration, but confirms it in the regression on voter turnout, while being significant both times. The other electoral types do not prove to be significant in the regressions and are not consistently of the expected signs.

Table 10. Independent samples t-test of post-communist versus not post-communist countries regarding net migration and voter turnout.

\begin{tabular}{lcccccccc}
\hline Variable & P.-C. & N & Mean & $\begin{array}{c}\text { Std. } \\
\text { Deviation }\end{array}$ & $\begin{array}{c}\text { Std. Error } \\
\text { Mean }\end{array}$ & t & df & $\begin{array}{c}\text { Sig. (2- } \\
\text { tailed) }\end{array}$ \\
\hline $\begin{array}{l}\text { Net } \\
\text { Migration }\end{array}$ & 0 & 25 & 643955 & 1143812 & 228762.40674 & 2.688 & 50 & 0.01 \\
& 1 & 27 & 10278 & 424067 & 81611.91861 & & & \\
Voter & 0 & 25 & .7579 & .12725 & .02545 & 3.703 & 50 & 0.001 \\
Turnout & & 27 & .6223 & .13626 & .02622 & & & \\
& 1 & 27 & & & & & & \\
\hline
\end{tabular}




\section{Ethnic Group Representativeness}

Table 11. OLS regressions with dependent variables net migration, voter turnout, protest and rebellion.

\begin{tabular}{|c|c|c|c|c|c|c|c|c|}
\hline \multirow{2}{*}{$\begin{array}{l}\text { Dependent } \\
\text { Variable: }\end{array}$} & \multicolumn{2}{|c|}{ Net Migration } & \multicolumn{2}{|c|}{ Voter Turnout } & \multicolumn{2}{|c|}{ Protest } & \multicolumn{2}{|c|}{ Rebellion } \\
\hline & ES & ET & ES & ET & ES & ET & ES & ET \\
\hline $\bar{C}$ & 4038958. ${ }^{* \star \star}$ & $2996848 .^{* *}$ & $0.510229^{* \star}$ & $0.696455^{\star \star \star}$ & $6.957659^{\star \star \star}$ & $6.381241^{* * *}$ & 0.092634 & 0.190297 \\
\hline \multirow[t]{2}{*}{ ENPP } & $-159322.8^{*}$ & -154666.0 & -0.008948 & -0.011121 & -0.105362 & -0.064461 & - & -0.020862 \\
\hline & & & & & & & 0.028962 & \\
\hline \multirow[t]{2}{*}{ ES_Mixed } & -595545.9 & & 0.104623 & & -0.065323 & & - & \\
\hline & & & & & & & 0.015295 & \\
\hline ES_PR & -585170.4 & & 0.084629 & & -0.694974 & & 0.017954 & \\
\hline ET_AV & & 286040.2 & & 0.132486 & & 1.225824 & & 0.211137 \\
\hline ET_FPTP & & 1093688.* & & $-0.226037^{\star *}$ & & 0.383344 & & -0.057237 \\
\hline ET_List PR & & 11999.70 & & -0.024514 & & -0.359413 & & -0.048785 \\
\hline ET_MMP & & -196911.0 & & 0.005517 & & $0.970867^{*}$ & & -0.114382 \\
\hline ET_STV & & -345021.8 & & -0.015867 & & 1.088178 & & $0.397799^{*}$ \\
\hline ET_TRS & & -143320.7 & & -0.032101 & & 0.289161 & & -0.046566 \\
\hline Seats- & $-3140884 .^{\star \star}$ & $-2513521 . *$ & 0.203003 & 0.099303 & $-5.129148^{\star \star \star}$ & $-5.365305^{\star \star \star}$ & 0.049062 & -0.124730 \\
\hline \multicolumn{9}{|l|}{ Population } \\
\hline \multicolumn{9}{|l|}{ Ratio } \\
\hline GDP & 21.00006 & 15.73782 & $-3.98 E-07$ & 5.39E-07 & $-1.22 \mathrm{E}-06$ & 1.26E-06 & $6.48 \mathrm{E}-07$ & 2.37E-06 \\
\hline PoRi_Index & -53667.10 & -22312.06 & $0.028399^{* *}$ & $0.026485^{\star}$ & $-0.295938^{* * *}$ & $-0.258895^{\star *}$ & 0.027128 & 0.026463 \\
\hline Post- & -163889.6 & -278060.1 & - & - & 0.280154 & 0.440818 & - & 0.043516 \\
\hline Communist & & & $0.207427^{\star \star \star}$ & $0.191689^{\star \star \star}$ & & & 0.012753 & \\
\hline $\mathrm{R} 2$ & 0.348324 & 0.413768 & 0.373749 & 0.491636 & 0.381454 & 0.500709 & 0.065613 & 0.213036 \\
\hline \multirow[t]{2}{*}{ Adjusted R2 } & 0.239711 & & & & 0.278363 & 0.356177 & - & -0.014770 \\
\hline & & 0.244069 & 0.269374 & 0.344479 & & & 0.090118 & \\
\hline
\end{tabular}

The fact that Table 11 shows different significance patterns than Table 7 hints that the three determinants of representativeness, ENPP, electoral system, electoral type and share ratio, might not be able to predict largely differing responses to underrepresentation of ethnic groups. While they are strong predictors of protest index scores, they fail to predict voter turnout, net migration and rebellion in a way that is consistent with theory. The dependent variables used in the empirical analysis are unlikely to be comparable responses to underrepresentation. This is because they cannot be easily interpreted as lying on a continuum of responses to underrepresentation that increases in severity. Table 12 shows the correlations between the alternative dependent variables. It reveals only a slightly significant but small correlation between net migration and protest. This suggests that the alternatives are not necessarily comparable responses to underrepresentation. The kind of reaction that members of ethnic groups chose when being confronted with political underrepresentation is likely to depend on cultural factors, rule of law, media coverage and other factors. These country characteristics are not observed in the research at hand and are 


\section{Ethnic Group Representativeness}

likely to induce an omitted variable bias. This section has therefore failed to prove the robustness of the determinants of representativeness. Including further variables might however show their explanatory strength on varying responses to underrepresentation.

Table 12. Correlations dependent variable alternatives

\begin{tabular}{lcccc}
\hline Indicant & $\mathbf{1}$ & $\mathbf{2}$ & $\mathbf{3}$ & $\mathbf{4}$ \\
\hline Protest & 1 & & & \\
Rebellion & $.324^{\star}$ & 1 & & \\
Net Migration & $.289^{*}$ & .188 & 1 & \\
Voter Turnout & -.155 & -.131 & -.009 & 1 \\
\hline Note. ${ }^{*}$ Correlation is significant at the 0.05 level (2-tailed).
\end{tabular}

\section{Discussion}

The theory developed in this paper predicts that higher representativeness of ethnic minority groups leads to less conflict in affected countries. Being adequately represented in a country's government gives ethnic minority groups the opportunity to influence political decision-making and voice their opinion. If a group is not adequately represented it might opt out of the normal political process and try to voice its opinion by means of violent conflict or riot. From an extensive literature review three potential determinants of representativeness are extracted. Firstly, a higher effective number of parties in parliament, ENPP, leads to more groups being represented and should thus reduce conflict. Secondly, a more proportional electoral system and electoral type is better suited to mirror the fragmentation of the population in government and should thus give each ethnic group satisfactory representation and thus less need for conflict. Lastly, a higher share of seats occupied by parties classified as ethnic relative to the share of a country's population held by ethnopolitical groups gives those groups effective representation and decision-making influence and thus reduces conflict.

The hypothesis about the effect of the effective number of parties in parliament on conflict was not proven by the statistical analysis conducted in section four. Tables 7 and 8 consistently show negative coefficients on the ENPP and thus conform to the findings of Powell (1981, 1982), who finds a negative effect of the degree of party systems fractionalization on the frequency of riots (Powell, 1981, p. 870). However, the analysis does not show any significance of the coefficients. There are two important potential causes for the missing confirmation of the developed theory. While the number of parties increases with district magnitude as Duverger's law (Duverger, 1954) suggests, Taagepera and Shugart (1989) argue that this link might also increase vote-seat disproportionality depending on the 


\section{Ethnic Group Representativeness}

formula used to translate votes into seats. A high Effective Number of Parties in Parliament might moreover lead to high coordination costs and government instability, because the amount of issues to be discussed and disagreed on rises (Powell, 2004).Decreasing thresholds of votes, that parties have to meet in order to enter parliament further increase the number of parties. Misrepresentation due to vote-seat disproportionality is likely to lead minority groups to be unsatisfied with their representation and to voice their opinion in other ways. This line of argumentation conflicts with the relation hypothesized above and potentially decreases the significance and size of the coefficient found in the empirical analysis. A second potential cause is a low linkage between ethnic minority groups and political parties. This problem will be analyzed in more detail later.

The empirical analysis did not give consistent prove of the hypothesis that a more proportional electoral system or electoral type leads to less conflict. While both an electoral system of proportional representation and the electoral type of list proportional representation almost consistently show less conflict than a majority electoral system or a parallel electoral type respectively, and thus give support for the findings of Powell (1981), the coefficients are not significant. Only a mixed-member proportional and a single transferable vote electoral type show significant relationships. These are however likely to be biased by unobserved country characteristics. Potential reasons are a bias in the sample used for the analysis and again a low linkage between ethnic minority groups and political parties, which will be analyzed later. Of the sample of 52 countries, 62 percent use an electoral system of proportional representation and 58 percent use the electoral type of list proportional representation. Thus proportional representation electoral systems and types are largely overrepresented, which likely leads to biased results. A sample of countries with more diverse use of electoral systems and types might yield differing results and support Powell's findings. Tables 7, 8 and 11 all show that replacing the electoral system with different electoral types in regression analysis largely increases the explanatory power of the regression, measured by the $\mathrm{R}$-square. This suggests that not every electoral type that is used under the heading of proportional representation or plurality rule has the same effect on conflict as other electoral types of the same category. Most of the literature on the topic is concerned with the effect of the choice of electoral system on conflict and violence. A more thorough analysis of the effects of different electoral types could lead to conflicting results and is a potential direction for further research.

The last determinant of representativeness included in the theory is the ratio of the share of seats of ethnic parties divided by the share of the population held by ethnopolitical groups. The hypothesis concerning this variable was consistently proven by the statistical analysis 


\section{Ethnic Group Representativeness}

and is robust to the exclusion of outliers. These findings provide strong support for the argumentation of Alonso and Ruiz-Rufino (2007). Compared to the insignificance of the coefficients of the ENPP and both the electoral system and the electoral type, it seems that it is the actual degree of representation of ethnic groups in parliaments that matters to contain violence, as opposed to the mere possibility of representation given by a proportional electoral system or a large number of parties. However, the significance and robustness of the results should be interpreted with caution. Here the effect of a missing linkage between ethnic groups and ethnic parties comes into play again.

As becomes obvious when comparing tables A2 and A3 in the appendix, by far not every ethnopolitical group is represented by an individual party classified as ethnic by Lane, McKay and Newton (1997) in its country. While some groups are not represented by parties at all (such as the South Tyrolians in Italy), other ethnopolitical groups are represented by more than one party (such as the Albanians in Macedonia). This has the potential result that, although the share of ethnic parties in parliament increases, individual ethnopolitical groups are not effectively represented in a more proportional way. They thus still have an incentive to use conflict to voice their opinion and influence political decision-making. For the determinants of representativeness used in the statistical analysis this means that the coefficients might not fully capture the degree of representativeness that they were supposed to approximate. An increase in the effective number of parties does not result in more ethnic groups being represented, if the linkage between groups and parties is low. The same argumentation holds for the electoral system and electoral type. A system of proportional representation results in more parties than a plurality rule system and should thus also represent more ethnic groups, which it does not if added parties are not directly linked to individual ethnic groups. For the ratio of share of seats of ethnic parties divided by share of the population held by ethnopolitical group a low group-party linkage means, that proportionality cannot be fully assessed, because the two parts of the ratio are not related to the same ethnic groups. A higher ratio could mean that one ethnic minority group is overrepresented while another group is still underrepresented.

The low-linkage problem arises partly due to the lack of a coherent database. While data on ENPP and share of seats of ethnic parties comes from the Comparative Political Data Set (Armingeon et al., 2013), data on the population shares of ethnopolitical groups are taken out of the Minorities at Risk database (MAR, 2009). Finding or creating a coherent database with matching data on all variables exceeds the scope of this paper and might rather be suitable for a master thesis. This lack of a coherent database presents a limitation to the research at hand. Nevertheless, a complete linkage between ethnic groups and parties is potentially 


\section{Ethnic Group Representativeness}

unreachable, since not all groups seek having a party that solely represents their interests. In light of the recent integration debates in several countries, a complete linkage would moreover not be desirable. Several ethnic minority groups in the countries included in the sample are integrated into society to a degree that their interests align with the interests of the rest of the population. Members of these ethnic groups are integrated into and thus represented in existing bigger parties, so that there is no need for separate ethnic parties. Examples are given by politicians such as Cem Özdemir, who is of Turkish descent and a member of the German Green party, or the African-American president of the United States, Barack Obama, who is a member of the American Democratic party. In diverse yet integrated societies it is rather usual for parties to consist of and thus represent more than one ethnic group.

Due to the lack of a coherent data source and due to missing data, the empirical analysis had to be limited to a cross-section analysis. Further research into the topic, based on more coherent data could potentially repeat the analysis in a time-series or panel data way. This might yield more insights and prove the theory this paper establishes. Furthermore, expanding the sample to include countries from Africa, South America, the Middle East and Asia can potentially yield further insights. A broader sample could yield interesting results, especially in the light of cultural differences, that might enhance differing responses to underrepresentation. Ethnic minority groups in these regions have been involved in several conflicts and could have higher tendencies to engage in violent conflict.

\section{Conclusion}

This research paper addresses the question whether underrepresentation of ethnic minority groups in governments leads to higher levels of conflict in affected countries. Groups that experience higher degrees of representativeness are hypothesized to be able to influence political decision-making and are thus less involved in violent conflict. The empirical tests presented in this paper show that a relationship between representativeness and conflict does exist. The ratio of the share of seats of ethnic parties in parliament divided by the share of the population held by ethnopolitical groups has the most explanatory power in predicting protest scores. It is the only consistently significant determinant of representativeness. Therefore only one part of the developed theory can be proven by means of data analysis. An interpretation of the results should be done with caution due to data limitations and an apparent mismatch between ethnic parties and ethnic groups. Furthermore the theory only yields correct predictions when looking at protest levels as dependent variables. This suggests that representativeness is not a reliable predictor of stronger levels of violence, such as the Minorities at Risk rebellion scores, or of other potential responses to 


\section{Ethnic Group Representativeness}

underrepresentation of ethnic groups, such as a decrease in voter turnout or an increase in emigration.

As North, Wallis and Weingast (2009) argue, countries that experience high levels of conflict encounter lower levels of economic prosperity. Table 13 shows an OLS regression of all variables involved in the analysis and examines GDP growth as the dependent variable. Adding protest as explanatory variable increases the explanatory power of the regression by more than 50 percent. This provides strong support for the theory of North et al. (2009).

Table 13. OLS regressions with dependent variable GDP growth

\begin{tabular}{|c|c|c|c|c|}
\hline \multicolumn{5}{|c|}{ Dependent Variable: GDP Growth } \\
\hline \multirow{2}{*}{$\begin{array}{l}\text { Variable } \\
\text { C }\end{array}$} & \multicolumn{2}{|c|}{ Electoral System } & \multicolumn{2}{|c|}{ Electoral Type } \\
\hline & $2.284075^{\star \star \star}$ & $-0.252735^{\star \star \star}$ & $2.463647^{\star \star \star}$ & -0.058510 \\
\hline ENPP & -0.031657 & 0.000340 & -0.012675 & 0.001816 \\
\hline ES_Mixed & 0.099134 & 0.016299 & & \\
\hline ES_PR & -0.126621 & 0.056932 & & \\
\hline ET_AV & & & 0.474992 & 0.047647 \\
\hline ET_FPTP & & & -0.213570 & $-0.107334^{* *}$ \\
\hline ET_List PR & & & -0.173340 & -0.005476 \\
\hline ET_MMP & & & 0.296763 & -0.069313 \\
\hline ET_STV & & & $0.493909^{*}$ & $0.121254^{*}$ \\
\hline ET_TRS & & & 0.043185 & -0.007154 \\
\hline Net Migration & $6.73 E-08$ & $1.50 \mathrm{E}-08$ & $1.07 \mathrm{E}-07^{\star}$ & $2.53 \mathrm{E}-08^{*}$ \\
\hline PoRi Index & $-0.064648^{\star *}$ & $0.019738^{* *}$ & -0.049430 & $0.014766^{*}$ \\
\hline Share Ratio & $-1.316199^{\star \star}$ & $0.530475^{\star * *}$ & $-1.397357^{* * *}$ & $0.438065^{\star * *}$ \\
\hline Voter Turnout & -0.210681 & -0.028668 & -0.523657 & -0.100174 \\
\hline Protest & & $0.377765^{\star \star *}$ & & $0.368885^{\star * *}$ \\
\hline $\mathrm{R}^{2}$ & 0.284801 & 0.964275 & 0.465894 & 0.972525 \\
\hline Adjusted $R^{2}$ & 0.165601 & 0.957304 & 0.311284 & 0.963614 \\
\hline
\end{tabular}

This result has important theoretical implications. While conflict might on one hand induce positive change that leads to an increase in citizens' well-being, for example when corrupt governments are overthrown, it can also significantly decrease economic prosperity in the long-run. Countries that are in a transition or infancy period, where they have the power to shape their government, would be well-advised to grant appropriate proportional representation to all ethnic minority groups. This can greatly improve the citizens' long-run well-being by resulting in high GDP growth. 


\section{Ethnic Group Representativeness}

\section{Appendix}

8.1 Country sample

Table A1. Country sample summary

\begin{tabular}{|c|c|c|c|c|}
\hline \multirow[t]{2}{*}{ Country } & OECD Members & \multirow{2}{*}{$\begin{array}{l}\text { EU Members } \\
\mathrm{n}=28\end{array}$} & \multirow{2}{*}{$\begin{array}{l}\text { Both } \\
n=21\end{array}$} & \multirow{2}{*}{$\begin{array}{l}\text { Neither } \\
n=15\end{array}$} \\
\hline & $n=29$ & & & \\
\hline Albania & & & & $x$ \\
\hline Armenia & & & & $x$ \\
\hline Australia & $x$ & & & \\
\hline Austria & $x$ & $x$ & $x$ & \\
\hline Azerbaijan & & & & $x$ \\
\hline Belarus & & & & $x$ \\
\hline $\begin{array}{l}\text { Belgium } \\
\text { Bosnia- } \\
\text { Herzegovina }\end{array}$ & $x$ & $x$ & $x$ & $x$ \\
\hline Bulgaria & & $x$ & & \\
\hline Canada & $x$ & & & \\
\hline Croatia & & $x$ & & \\
\hline Cyprus & & $x$ & & \\
\hline Czech Republic & $x$ & $x$ & $x$ & \\
\hline Denmark & $x$ & $x$ & $x$ & \\
\hline Estonia & $x$ & $x$ & $x$ & \\
\hline Finland & $x$ & $x$ & $x$ & \\
\hline France & $x$ & $x$ & $x$ & \\
\hline Georgia & & & & $x$ \\
\hline Germany & $x$ & $x$ & $x$ & \\
\hline Greece & $x$ & $x$ & $x$ & \\
\hline Hungary & $x$ & $x$ & $x$ & \\
\hline Iceland & $x$ & & & \\
\hline Ireland & $x$ & $x$ & $x$ & \\
\hline Italy & $x$ & $x$ & $x$ & \\
\hline Japan & $x$ & & & \\
\hline $\begin{array}{l}\text { Kazakhstan } \\
\text { Kyrgyz } \\
\text { Republic }\end{array}$ & & & & $x$ \\
\hline Latvia & & $x$ & & \\
\hline Lithuania & & $x$ & & \\
\hline Luxembourg & $x$ & $x$ & $x$ & \\
\hline Macedonia & & & & \\
\hline Malta & & $x$ & & \\
\hline Moldava & & & & $x$ \\
\hline Mongolia & & & & $x$ \\
\hline Netherlands & $x$ & $x$ & $x$ & \\
\hline New Zealand & $x$ & & & \\
\hline Norway & $x$ & & & \\
\hline Poland & $x$ & $x$ & $x$ & \\
\hline Portugal & $x$ & $x$ & $x$ & \\
\hline Romania & & $x$ & & \\
\hline Russia & & & & $x$ \\
\hline
\end{tabular}




\section{Ethnic Group Representativeness}

\begin{tabular}{|c|c|c|c|c|}
\hline Slovakia & $x$ & $x$ & $x$ & \\
\hline Slovenia & $x$ & $x$ & $x$ & \\
\hline Spain & $x$ & $x$ & $x$ & \\
\hline Sweden & $x$ & $x$ & $x$ & \\
\hline Switzerland & $x$ & & & \\
\hline Tajikistan & & & & $x$ \\
\hline Turkmenistan & & & & $x$ \\
\hline UK & $x$ & $x$ & $x$ & \\
\hline Ukraine & & & & $x$ \\
\hline USA & $x$ & & & \\
\hline Uzbekistan & & & & $x$ \\
\hline
\end{tabular}

\subsection{Party classifications}

Table A2. Parties classified as ethnic for each country in the sample

\begin{tabular}{|c|c|}
\hline \multirow{3}{*}{$\begin{array}{l}\text { Country } \\
\text { Albania }\end{array}$} & Parties \\
\hline & Omonia Democratic Union \\
\hline & Human Rights Union Party (Bashkimi i të Drejtave të Njeriut) \\
\hline Armenia & None \\
\hline Australia & None \\
\hline Austria & None \\
\hline Azerbaijan & None \\
\hline Belarus & None \\
\hline Belgium & $\begin{array}{l}\text { New Flemish Alliance (Nieuw-Vlaamse Alliantie, N-VA) (former: Flem- } \\
\text { ish/People's Union (VU)) }\end{array}$ \\
\hline $\begin{array}{l}\text { Bosnia- } \\
\text { Herzegovina }\end{array}$ & None \\
\hline Bulgaria & $\begin{array}{l}\text { Movement for Rights and Freedoms (Dvizhenie za Prava I Svobodi, } \\
\text { DPS) } \\
\text { Coalition Movement for Rights and Freedoms (Dviženie za Pravata i } \\
\text { Svobodie) [comprised of Movement for Rights and Freedoms, (Dviženie } \\
\text { za Pravata i Svo-bodie); Liberal Union (Liberalen Sajuz) and Euroroma } \\
\text { (Evroroma)] } \\
\text { George Day-International Macedonian Revolutionary Organization } \\
\text { (VMRO-Gergiovden) }\end{array}$ \\
\hline Canada & Bloc Québécois \\
\hline Croatia & $\begin{array}{l}\text { Serbian Democratic Party (Srpska Demokratska Stranka, SDS) } \\
\text { Serbian National Party (Srpska Narodna Stranka, SNS) }\end{array}$ \\
\hline Cyprus & None \\
\hline Czech Republic & None \\
\hline Denmark & None \\
\hline Estonia & $\begin{array}{l}\text { Our Home is Estonia (Meie Kodu on Estimaa, MKE) [comprised of } \\
\text { United People's Party; Russian Party; Estonian Russian People's Party] } \\
\text { Estonian United People's Party (Eesti Uhendatud Rahvapartei / } \\
\text { Obedinennaya Narodnaya Partya Estonii) } \\
\text { Russian Party in Estonia (Vene Erakond Eestis, VEE) }\end{array}$ \\
\hline Finland & Swedish People's Party (Svenska Folkepartiet I Finland, SFP/RKP) \\
\hline France & None \\
\hline Georgia & None \\
\hline
\end{tabular}




\section{Ethnic Group Representativeness}

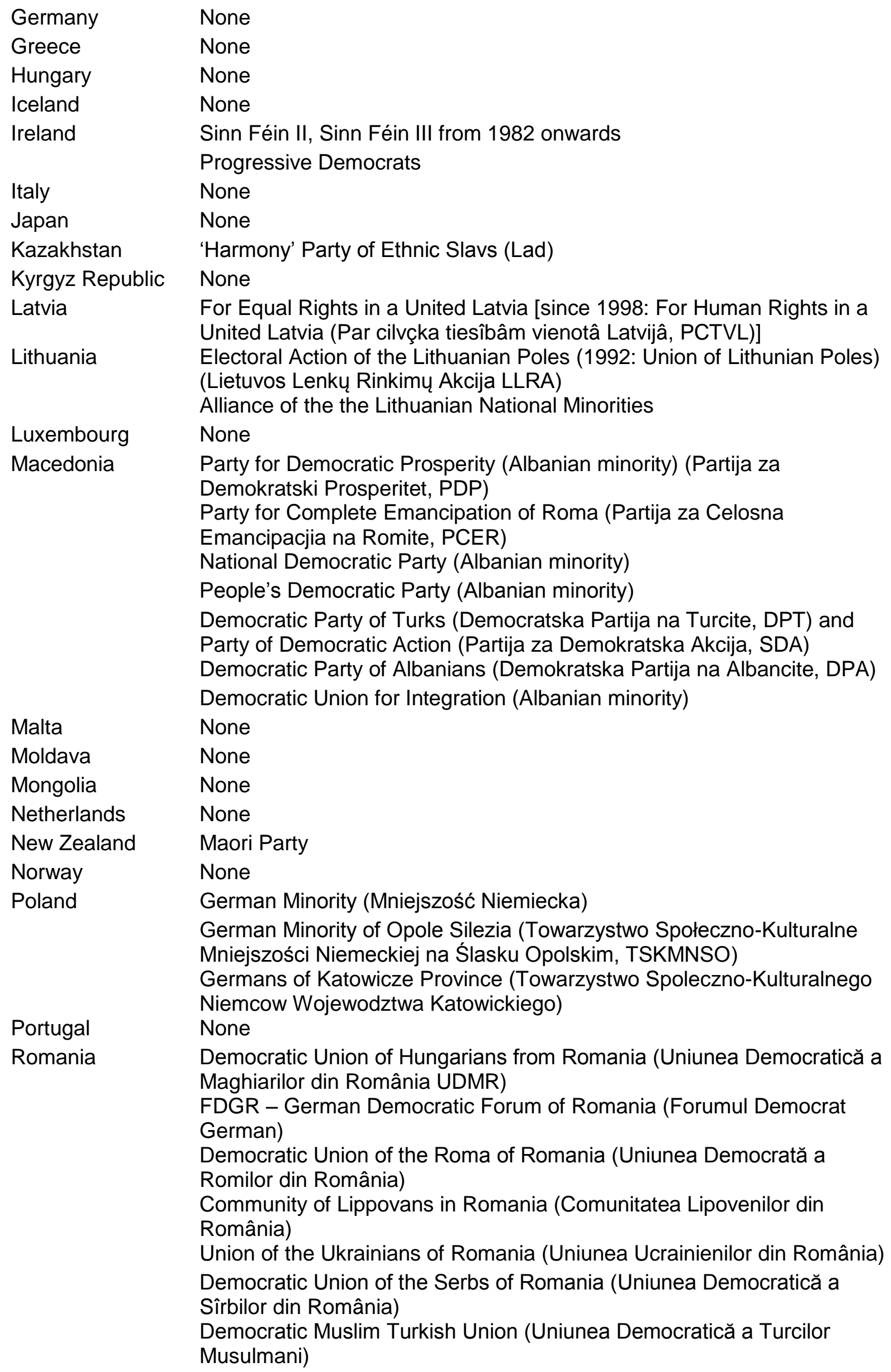




\section{Ethnic Group Representativeness}

\begin{tabular}{|c|c|}
\hline & Hellenic Union of Romania (Uniunea Elenă din România) \\
\hline & $\begin{array}{l}\text { Democratic Union of Slovaks and Czechs of Romania (Uniunea } \\
\text { Democratică a Slovacilor şi Cehilor din România) } \\
\text { Bulgarian Union of Banat - Bulgarian Cultural Association from } \\
\text { Bucharest (Uniunea Bulgară din Banat - Asociaţia Culturală Bulgară din } \\
\text { Bucureşti) } \\
\text { Union of Poles of Romania 'Dom Polski' (Uniunea Polonezilor din } \\
\text { România "Dom Polski") } \\
\text { Union of Armenians of Romania (Uniunea Armenilor din România) }\end{array}$ \\
\hline & $\begin{array}{l}\text { Italian Community in Romania - Trei lerarhi Street - Iaşi (Comunitatea } \\
\text { Italiană din România, Str. Trei lerarhi, Nr.2, Iaşi) } \\
\text { Democratic Union of Turkish Muslim Tatars from Romania (Uniunea } \\
\text { Democratică a tătarilor turco musulmani din România) } \\
\text { Federation of Jewish Communities in Romania (Federaţia Comunităţilor } \\
\text { Evreieşti din România) } \\
\text { League of Albanians from Romania (Liga Albanezilor din România) }\end{array}$ \\
\hline & Union of Croatians from Romania (Uniunea Croaţilor din România) \\
\hline & Cultural Union of Ruthens (Uniunea Culturală a Rutenilor) \\
\hline & $\begin{array}{l}\text { Democratic Union of Slavs MaceNoneans (Uniunea Democratâ a } \\
\text { Slavilor Macedonieni) }\end{array}$ \\
\hline & $\begin{array}{l}\text { Union of All-Associations of Hutul ethnic group from Romania (Uniunea } \\
\text { generală a asociaţiilor etniei hutule din România) }\end{array}$ \\
\hline Russia & None \\
\hline \multirow[t]{2}{*}{ Slovakia } & Coexistence and Hungarian Christian Democratic Movement \\
\hline & $\begin{array}{l}\text { Party of the Hungarian Coalition (Magyar Koalitio Partja, SMK) (1994: } \\
\text { Hungarian Coalition) } \\
\text { Hungarian Civic Party (Magyar Polgári Párt - Mad'arská obcanská } \\
\text { strana, MPP-MOS) } \\
\text { The Bridge (Most-Híd) }\end{array}$ \\
\hline Slovenia & $\begin{array}{l}\text { representative of Hungarian minority } \\
\text { representative of Italian minority }\end{array}$ \\
\hline \multirow[t]{2}{*}{ Spain } & Convergence and Unity (Convergéncia y Unió, CiU) \\
\hline & Catalonian Left Republicans (Esquerra Republicana de Catalunya, ERC) \\
\hline Sweden & None \\
\hline Switzerland & None \\
\hline Tajikistan & None \\
\hline Turkmenistan & None \\
\hline UK & Scottish National Party (SNP) \\
\hline Ukraine & None \\
\hline USA & None \\
\hline Uzbekistan & None \\
\hline
\end{tabular}




\section{Ethnic Group Representativeness}

\subsection{Ethnopolitical Groups}

Table A3. Ethnic groups meeting criteria to be identified as ethnopolitical

\begin{tabular}{|c|c|}
\hline Country & Groups meeting criteria \\
\hline Albania & Greeks \\
\hline Armenia & None \\
\hline Australia & Aborigines \\
\hline Austria & None \\
\hline \multirow[t]{2}{*}{ Azerbaijan } & Armenians \\
\hline & Lezgins \\
\hline \multirow[t]{2}{*}{ Belarus } & Russians \\
\hline & Poles \\
\hline Belgium & None \\
\hline \multirow[t]{3}{*}{ Bosnia-Herzegovina } & Serbs \\
\hline & Croats \\
\hline & Muslims \\
\hline \multirow{2}{*}{ Bulgaria } & Turks \\
\hline & Roma \\
\hline \multirow[t]{3}{*}{ Canada } & Quebecois \\
\hline & French Canadians \\
\hline & Indigenous Peoples \\
\hline Croatia & Serbs \\
\hline Cyprus & Turkish Cypriots \\
\hline \multirow{2}{*}{ Czech Republic } & Roma \\
\hline & Slovaks \\
\hline Denmark & None \\
\hline Estonia & Russians \\
\hline Finland & None \\
\hline \multirow[t]{4}{*}{ France } & Basques \\
\hline & Corsicans \\
\hline & Muslim (Noncitizens) \\
\hline & Roma \\
\hline \multirow[t]{4}{*}{ Georgia } & Abkhazians \\
\hline & Adzhars \\
\hline & Ossetians (South) \\
\hline & Russians \\
\hline Germany & Turks \\
\hline \multirow{2}{*}{ Greece } & Muslims \\
\hline & Roma \\
\hline Hungary & Roma \\
\hline Iceland & None \\
\hline Ireland & Catholics in Northern Ireland \\
\hline \multirow[t]{3}{*}{ Italy } & South Tyrolians \\
\hline & Sardinians \\
\hline & Roma \\
\hline Japan & Koreans \\
\hline \multirow[t]{2}{*}{ Kazakhstan } & Russians \\
\hline & Germans \\
\hline \multirow{2}{*}{ Kyrgyz Republic } & Russians \\
\hline & Uzbeks \\
\hline Latvia & Russians \\
\hline \multirow[t]{2}{*}{ Lithuania } & Poles \\
\hline & Russians \\
\hline Luxembourg & None \\
\hline \multirow[t]{2}{*}{ Macedonia } & Albanians \\
\hline & Serbs \\
\hline
\end{tabular}




\section{Ethnic Group Representativeness}

\begin{tabular}{|c|c|}
\hline & Roma \\
\hline Malta & None \\
\hline \multirow[t]{2}{*}{ Moldova } & Gagauz \\
\hline & Slavs \\
\hline Mongolia & None \\
\hline Netherlands & None \\
\hline New Zealand & Maori \\
\hline Norway & None \\
\hline Poland & None \\
\hline Portugal & None \\
\hline \multirow[t]{2}{*}{ Romania } & Magyars (Hungarians) \\
\hline & Roma \\
\hline \multirow[t]{11}{*}{ Russia } & Chechens \\
\hline & Tatars \\
\hline & Karachay \\
\hline & Roma \\
\hline & Avars \\
\hline & Ingush \\
\hline & Lezgins \\
\hline & Buryat \\
\hline & Kumyks \\
\hline & Tuvinians \\
\hline & Yakut \\
\hline \multirow[t]{2}{*}{ Slovakia } & Hungarians \\
\hline & Roma \\
\hline Slovenia & None \\
\hline \multirow[t]{3}{*}{ Spain } & Basques \\
\hline & Catalans \\
\hline & Roma \\
\hline Sweden & None \\
\hline \multirow{2}{*}{ Switzerland } & Jurassians \\
\hline & Foreign Workers \\
\hline \multirow[t]{2}{*}{ Tajikistan } & Russians \\
\hline & Uzbeks \\
\hline Turkmenistan & Russians \\
\hline \multirow[t]{3}{*}{ United Kingdom } & Scots \\
\hline & Afro-Caribbeans \\
\hline & Asians \\
\hline \multirow[t]{3}{*}{ Ukraine } & Russians \\
\hline & Crimean Tatars \\
\hline & Crimean Russians \\
\hline \multirow[t]{4}{*}{ United States of America } & African-Americans \\
\hline & Hispanics \\
\hline & Native Americans \\
\hline & Native Hawaiians \\
\hline \multirow[t]{2}{*}{ Uzbekistan } & Russians \\
\hline & Tajiks \\
\hline
\end{tabular}




\section{Ethnic Group Representativeness}

8.4 Correlations

\begin{tabular}{|c|c|c|c|c|c|c|c|c|c|c|}
\hline Indicant & 1 & 2 & 3 & 4 & 5 & 6 & 7 & 8 & 9 & 10 \\
\hline $\begin{array}{l}\text { Electoral } \\
\text { System }\end{array}$ & 1 & & & & & & & & & \\
\hline $\begin{array}{l}\text { Electoral } \\
\text { Type }\end{array}$ & $.944^{* *}$ & 1 & & & & & & & & \\
\hline ENPP & .109 & .055 & 1 & & & & & & & \\
\hline Share Ratio & .056 & .092 & $.285^{-}$ & 1 & & & & & & \\
\hline Protest & .051 & .008 & -.052 & $383^{* *}$ & 1 & & & & & \\
\hline Rebellion & -.059 & .017 & -.194 & .030 & $.324^{*}$ & 1 & & & & \\
\hline GDP & -.201 & $-.284^{*}$ & .029 & $.324^{*}$ & $.048^{-}$ & $.030^{-}$ & 1 & & & \\
\hline PR Index & -.150 & -.013 & -.124 & $-.274^{*}$ &. & .120 & $.637^{-*}$ & 1 & & \\
\hline $\begin{array}{l}\text { Net } \\
\text { Migration }\end{array}$ & $297^{*}$ & $.380^{-*}$ & -.226 & -.121 & $.289^{*}$ & .188 & $.362^{* *}$ & $.182^{-}$ & 1 & \\
\hline $\begin{array}{l}\text { Voter } \\
\text { Turnout }\end{array}$ & -.024 & .067 & -.184 & $-.284^{*}$ & .155 & .131 & $.321^{*}$ & .053 & .009 & 1 \\
\hline
\end{tabular}




\section{Ethnic Group Representativeness}

\section{References}

Adams, J. (1776). Thoughts on government. Raleigh, NC: Hayes Barton Press.

Armingeon, K., Careja, R., Knöpfel, L., Weisstanner, D., Engler, S., Potolidis, P., Gerber, M. (2013). Comparative Political Data Set I, II \& III. Bern: Institute of Political Science, University of Bern.

Alonso, S., \& Ruiz-Rufino, R. (2007). Political representation and ethnic conflict in new democracies. European Journal of Political Research, 46(2), 237-267.

Bates, R. H. (2001). Prosperity and violence: the political economy of development. New York: WW Norton.

Busse, M., \& Hefeker, C. (2007). Political risk, institutions and foreign direct investment. European Journal of political economy, 23(2), 397-415.

Duverger, M., North, B., \& North, R. (1954). Political Parties: Their Organization and Activity in the Modern State: Translated by Barbara and Robert North. London: Methuen Publishing Ltd.

The Economist (2011). Springtime for them too? The Berbers join the Arab Revolt. Retrieved from http://www.economist.com/node/21525925

Freedom House (2014). Country ratings and status, FIW 1973-2014. Retrieved on 30/05/14 from http://www.freedomhouse.org/report-types/freedom-world\#.U5sN1ih9mXN

Htun, M. (2004). Is gender like ethnicity? The political representation of identity groups. Perspectives on Politics, 2(03), 439-458.

International Institute for Democracy and Electoral Assistance (2010). Voter Turnout Database. Retrieved on 12/05/14 from http://www.idea.int/vt/viewdata.cfm on

International Institute for Democracy and Electoral Assistance (2014). Table of Electoral Systems Worldwide. Retrieved on 02/05/14 from http://www.idea.int/esd/world.cfm

Laakso, M., \& Taagepera, R. (1979). Effective number of parties: A measure with application to West Europe. Comparative political studies, 12(1), 3-27.

Lane, J. E., McKay, D.H. \& Newton, K. (1997). Political Data Handbook OECD Countries. Oxford: Oxford University Press.

Lijphart, A. (1990). The political consequences of electoral laws, 1945-85. American Political Science Review, 84(2), 481-496.

Lijphart, A. (2012). Patterns of democracy: Government forms and performance in thirty-six countries. New Haven, CT: Yale University Press.

Matland, R. E., \& Studlar, D. T. (1996). The contagion of women candidates in singlemember district and proportional representation electoral systems: Canada and Norway. The journal of politics, 58(03), 707-733. 


\section{Ethnic Group Representativeness}

Minorities at Risk Project. (2009) Minorities at Risk Dataset. College Park, MD: Center for International Development and Conflict Management. Retrieved on 01/05/14 from http://www.cidcm.umd.edu/mar/

Mueller, D. (2003). Public Choice III. New York, NY: Cambridge University Press

Neto, O. A., \& Cox, G. W. (1997). Electoral institutions, cleavage structures, and the number of parties. American Journal of Political Science, 41(1), 149-174.

North, D. C., Wallis, J. J., \& Weingast, B. R. (2009). Violence and social orders: a conceptual framework for interpreting recorded human history. Cambridge: Cambridge University Press.

Powell Jr, G. B. (1981). Party systems and political system performance: voting participation, government stability and mass violence in contemporary democracies. The American Political Science Review, 75(4), 861-879.

Powell Jr, G. B. (1982). Contemporary democracies. Cambridge, MA: Harvard University Press.

Powell Jr, G. B. (2004). Political representation in comparative politics. Annual Review of Political Science, 7, 273-296.

Shugart, M., \& Wattenberg, M. P. (Eds.). (2001). Mixed-Member Electoral Systems: The Best of Both Worlds?. Oxford: Oxford University Press.

State Statistic Committee of Ukraine (2004). First All-National Population Census: historical, methodological, social, economic, ethnic aspects. Retrieved on 03/05/14 from: http://2001.ukrcensus.gov.ua/eng/publications/

Taagepera, R., \& Shugart, M. S. (1989). Seats and votes: The effects and determinants of electoral systems. New Haven, CT: Yale University Press.

Therolf, G. and Sandels, A. (2011, April 7). Minority Syria Kurds join protest, get concessions. San Francisco Chronicle. Retrieved from http://archive.today/0ALr\#selection-1737.0-1737.50

Worldbank (2014a). GDP per capita, PPP (current international \$). Retrieved on 25/05/14 from http://data.worldbank.org/indicator/NY.GDP.PCAP.PP.CD

Worldbank (2014b). Net migration. Retrieved on 30/05/14 from http://data.worldbank.org/indicator/SM.POP.NETM 